Original Article

\title{
Begonia muricata Blume and Begonia serratipetala Irmsch durability as indoor pot plant in Eka Karya Bali Botanic Garden
}

\author{
Siti Fatimah Hanum*, I Dewa Putu Darma, Ayyu Rahayu \\ Eka Karya Bali Botanic Garden, Research Centre for Plant Conservation and Botanical Garden, Indonesian Institute of Sciences (LIPI), Candikuning, \\ Baturiti, Tabanan, Bali, Indonesia 82191
}

Abstract

Begonia is very popular as a foliage plant and some begonia species grow up in pots. Begonia serratipetala and Begonia muricata are Indonesian begonia species that are well suited as indoor potted plants because of their leaf color and shape. In addition, the Bali Botanical Garden's landscape nursery would like to use these begonias for decoration in all buildings. However, it still needs to be studied how long the shelf life of the two begonias is in indoor environments in the highlands without air conditioning (AC). The aim of this study was to investigate the indoor shelf life of $B$. serratipetala and $B$. muricata. This research method consists of two steps. The first step was the acclimation phase and the second step was the indoor placement phase. Each begonia was repeated three times. Parameters studied included plant growth (plant height, leaves, leaf width, and leaf length) and environmental factors (sunlight intensity, air temperature, and humidity). The data were analyzed descriptively. Correlation analysis was used to determine the relationship between growth parameters and environmental factors. The result showed that both begonias ( $B$. muricata and $B$. serratipetala) have similar persistence to indoor begonia species within two weeks, the ideal time for plant replacement.

Keywords: Begonia muricata, Begonia serratipetala, durability, interiorscape, indoor plant, growth.

Received: 30 April 2021 Revised: 29 June 2021 Accepted: 30 June 2021

\section{Introduction}

Interior landscaping is the practice of designing, arranging, and caring for living plants inside a building (Surendranath and Rahul, 2016). The most attractive feature of house plants is their foliage. Foliage plants define as all plants grown for their beautiful leaves rather than flowers or fruit. Those plants with attractive foliage and/ or flower are able to survive and grow indoor (Chen et al., 2005a). The characteristic of foliage plants is their ability to tolerate low light intensity. Therefore, foliage plants are used primarily for interior decoration or interior plantscaping (Chen et al., 2003). According to Odeh and Guy (2017), indoor plants has therapeutic and health benefits such as reduced pain, anxiety following surgery and higher pain tolerance after surgery than patient without the presence of plant in their room. These potencies become catalysts in promoting foliage plant production and increasing their wholesale value (Chen et al., 2003).

Most foliage plants are native to the world's tropical or subtropical regions. Begonia is one important genus of foliage plants indigenous to tropical Africa (Chen et al., 2005a). Begonia is the fifth genus of flowering plants (Ginori et al., 2020). Until July 2021, based on the Begonia Resource Centre data, Begonia comprises of 2.032 species (Hughes et al., 2015). The distribution of Begonia diversity is uneven throughout tropical regions, with the greatest diversity in America and Asia $(>600$ species each) (Dewitte et al., 2011). Indonesia is

* Corresponding Author:
Siti Fatimah Hanum
Eka Karya Bali Botanic Garden, Research Centre for Plant
Conservation and Botanical Garden, Indonesian Institute of
Sciences (LIPI), Tabanan, Bali, Indonesia 82191.
Phone: +6282340949344 Fax: -
e-mail: sitifatimahhanum2004@yahoo.com

predicted having Begonia more than 200 species and 70 species of them located in Papua. Begonia distribution in Indonesia cover in Java, Sumatera, Kalimantan, Sulawesi, and Papua island (Smith et al., 1986). Meanwhile, the uniqueness and beauty of their leaves (i.e., their shape and color) make Begonia become a foliage plant. This plant is also a popular ornamental plant (Dewitte et al., 2011; Siregar, 2016; Efendi and Lailaty, 2018). This benefit makes the landscaping unit at Bali Botanic Garden want to use Begonia as an indoor pot plant in all buildings. But the information on how long this plant will survive indoor is limited.

Plant quality is a critical for determining the selection of plant types for indoor plants. Begonia thrives best in partially shaded areas because they are sensitive to bright light (Ginori et al., 2020). But each Begonia species has different optimal shading (Jeong et al., 2009). As Indonesian wild begonia species, B.muricata dan B.serratipetala have potency as indoor plants. Begonia serratipetala Irmsch collected from Biak island Papua is a robust plant, has red bronzy leaf color while Begonia muricata Blume collected from Sumatera, has little terna habitus, creeping and form a rhizome (Siregar, 2005). B.muricata has fiery red leaf color and suitable for pot plant because the size is short (Girmansyah, 2008). The results of this study are expected to become recommendations for basic information on the durability of begonias indoor pot plants. Thus, help landscaping unit to support the implementation of ex situ conservation in Bali Botanic Gardens office.

\section{Methods}

This research was conducted in Bali Botanic Garden, Candikuning, Baturiti, Tabanan, with an altitude of 1,250 $\mathrm{m}$ above sea level. The experiment was carried out from 
June until September 2013. The materials used in this experimental research were $B$. serratipetala and $B$. muricata, hummus, polybag size $25 \times 30 \mathrm{~cm}$ (Fig. 1).

The initial material consisted of $B$. serratipetala and B. muricata obtained from the propagation collection of Bali Botanic Garden nursery, which are ready for selling. The initial condition of $B$. serratipetala has a height of $26-39 \mathrm{~cm}$ and $15-17$ number of leaves, while $B$. muricata has a height of 20-24 cm and 6-14 number of leaves.

This research method consists of two-step. The first step was the acclimatization stage, and the second step was the indoor placement stage. The two types of Begonias are first acclimatized in the nursery for one month. Surendranath and Nashipudi (2016) explained that acclimatization aims to reduce the shaking that occurs when sun-leaved plants are placed in the shade by gradually reducing the light intensity. The planting media are filled to half their volume in polybags and then compacted. Then the begonia is planted and then filled with planting substrate until $3 / 4$ of the total volume of the polybag is reached. Each begonia is multiplied three times. Due to material limitations, there is only one plant in a multiplication. Then, the two types of begonias are placed in the Bali Botanical Garden office (indoors). The office has only one window facing west. Two indoor begonias are randomly placed near a glass window. In this way, the plants receive different environmental factors every day. The office has no air conditioning and no artificial light inside. Watering is done twice a week or as needed. The plants do not receive any additional fertilizer.

Parameters observed include plant growth (plant height, number of leaves, leaf width and length) and environmental factors (sunlight intensity, air temperature and humidity). Plant height increment was measured from the soil surface to the growing point. The number of leaves is calculated by counting the number of fully open leaves. Leaf length and width observations were made by measuring the length and width of the second and third leaf blades from above. Leaf length is measured by calculating the length of the leaf vertically from the leaf base to the leaf tip, while leaf width is recorded by measuring the leaf at the widest point of the leaf. When the observed leaf has fallen off, the observation is made on the next leaf. The indoor physical conditions were measured with a thermohygrometer every week at 08:00 and 12:00, while the light intensity was measured with a luxmeter every week at 12:00.

Observations were made every week. The first observation was made at the same time as the plants were transferred to the office. Observations were continued until the plants showed a decline in growth or there was no change in growth. Plant growth data were analyzed descriptively using a graph of growth parameters as a function of indoor time. A correlation analysis was also performed to determine the relationship between growth parameters and environmental factors.
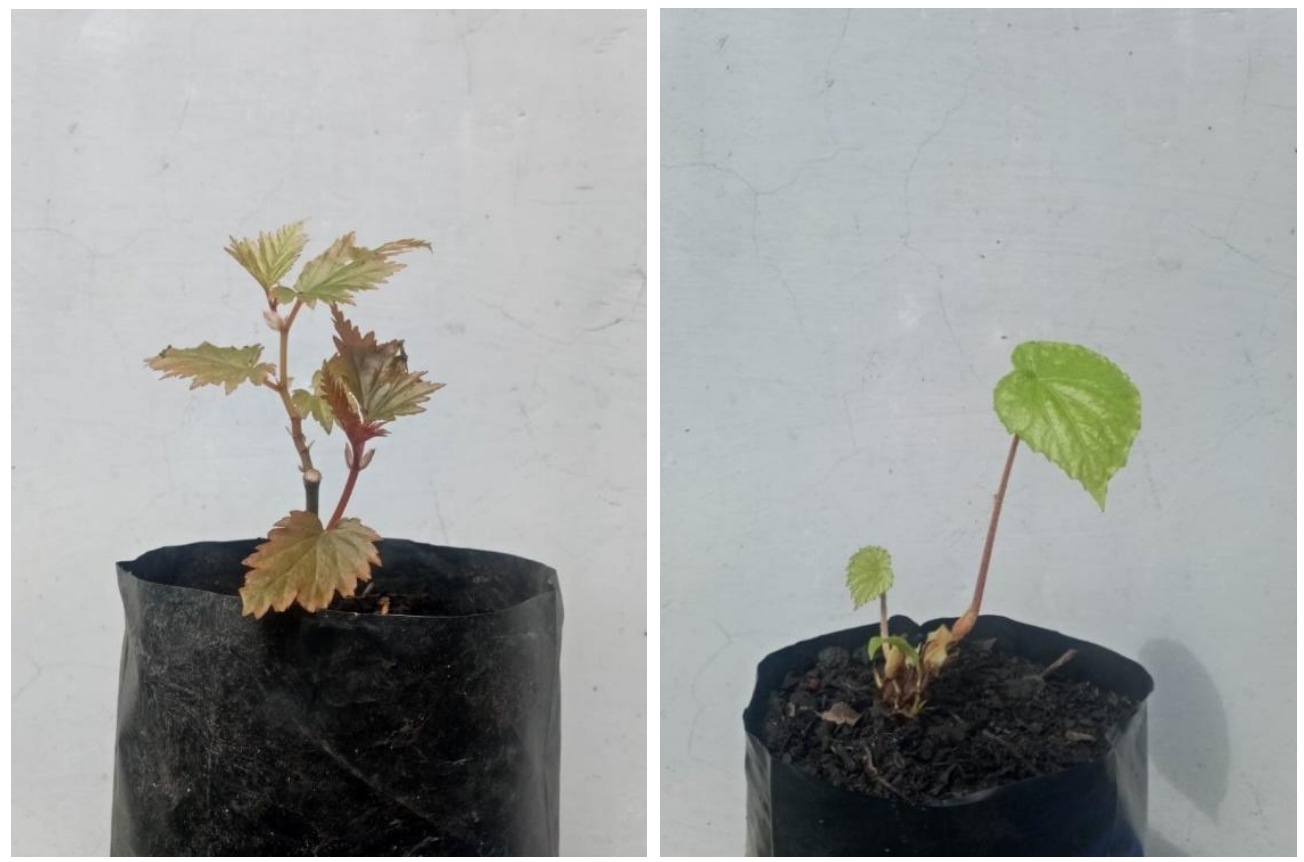

Figure 1. B. serratipetala (left) and B. muricata (right)

\section{Results}

Indoors, two types of begonias are placed next to a glass window, allowing plant growth to be influenced by different environmental factors each day. The daily temperature measurements ranged from 17.9 to $20.8^{\circ} \mathrm{C}$; Light intensity ranges from 24-121 Klux and humidity

range from $63.3-75.1 \%$ (Table 1 ). The light intensity at the study site only relies on afternoon sunlight entering through the window. This light intensity is still low for the two types of Begonias so that many shed leaves as time increases in the research office (indoor) 


\begin{tabular}{|c|c|c|c|c|}
\hline \multirow{2}{*}{ No } & \multirow{2}{*}{$\begin{array}{l}\text { duration time } \\
\text { (week) }\end{array}$} & \multicolumn{3}{|c|}{ the physical condition of the room } \\
\hline & & $\begin{array}{c}\text { relative humidity } \\
(\%)\end{array}$ & $\begin{array}{l}\text { light intensity } \\
\text { (Klux) }\end{array}$ & $\begin{array}{c}\text { air temperature } \\
\left({ }^{\circ} \mathrm{C}\right)\end{array}$ \\
\hline 1 & 0 & 74.70 & 24 & 18.60 \\
\hline 2 & 1 & 75.05 & 59 & 20.35 \\
\hline 3 & 2 & 72.70 & 52 & 17.90 \\
\hline 4 & 3 & 72.70 & 45 & 19.50 \\
\hline 5 & 4 & 67.50 & 97 & 19.60 \\
\hline 6 & 5 & 63.25 & 121 & 20.75 \\
\hline 7 & 6 & 72.70 & 59 & 19.60 \\
\hline
\end{tabular}

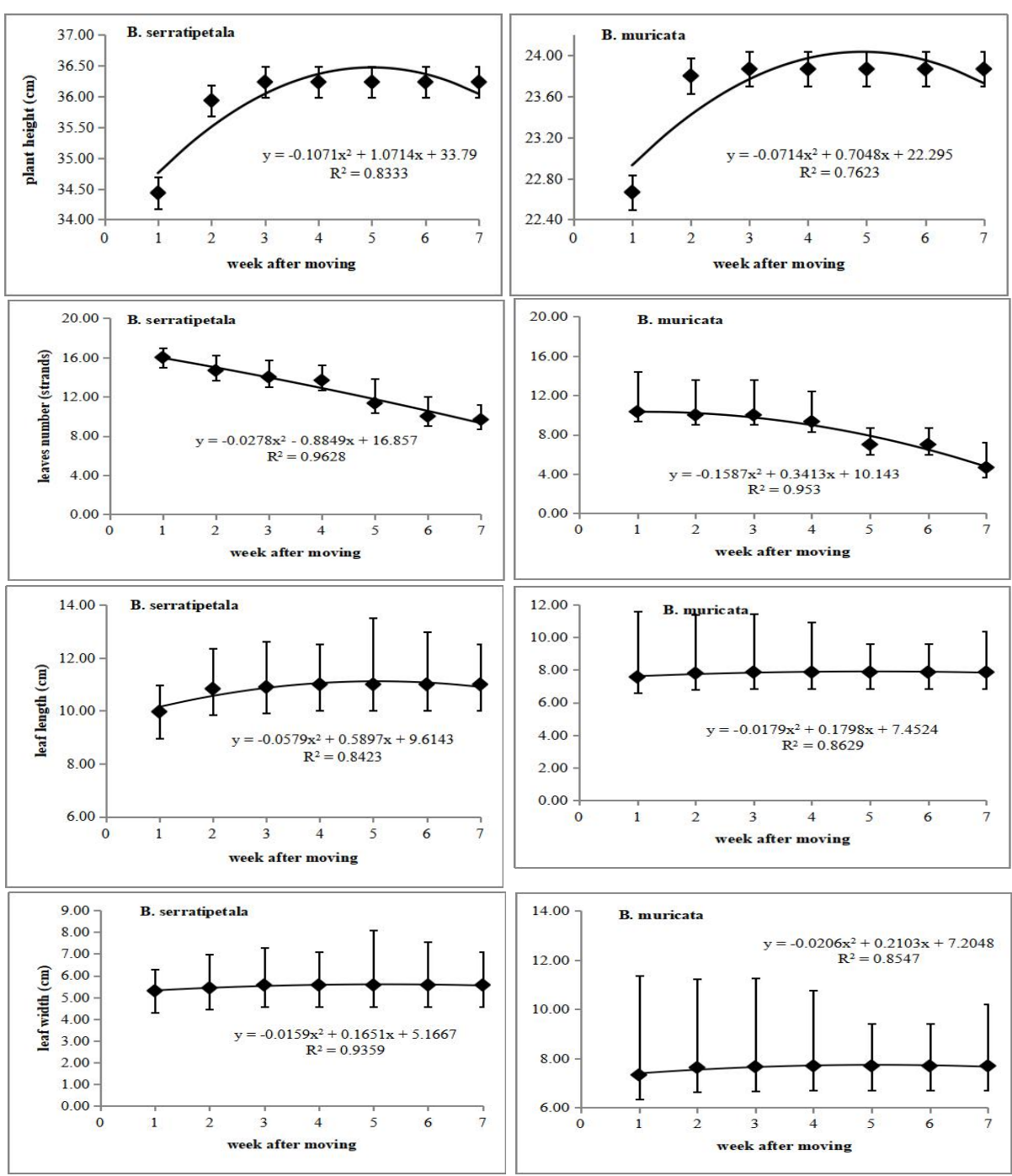

Figure 2. The plant height, leaves number, leaf length, and leaf width of $B$. serratipetala and B. muricata

The increases in the plant height and leaf width for two types of Begonias until the second week. The increases in leaf length until the third week (Fig. 2). The increase in plant height and leaf width in both $B$. serratipetala and $B$. muricata only occurred until the $2^{\text {nd }}$ week after the plants were transferred indoors. Meanwhile, the length of the leaves for both species continued to increase until $3^{\text {rd }}$ week. The number of leaves decreased with increasing duration. This is due to the presence of old leaves that wither and fall, while the new leaves have not yet formed and opened completely, so they are not counted as new leaves.
The correlation analysis results showed that environmental factors had different correlations to the growth parameters of the two types of Begonia observed (Table 2). The sunlight intensity factor has a significant correlation to all growth parameters. The intensity of sunlight has a positive correlation with the growth parameters of Begonia, except for the leaves number, which negatively correlates. Conversely, the air humidity factor positively correlates with leaf number and negatively correlates with plant height, leaf length, and width. 


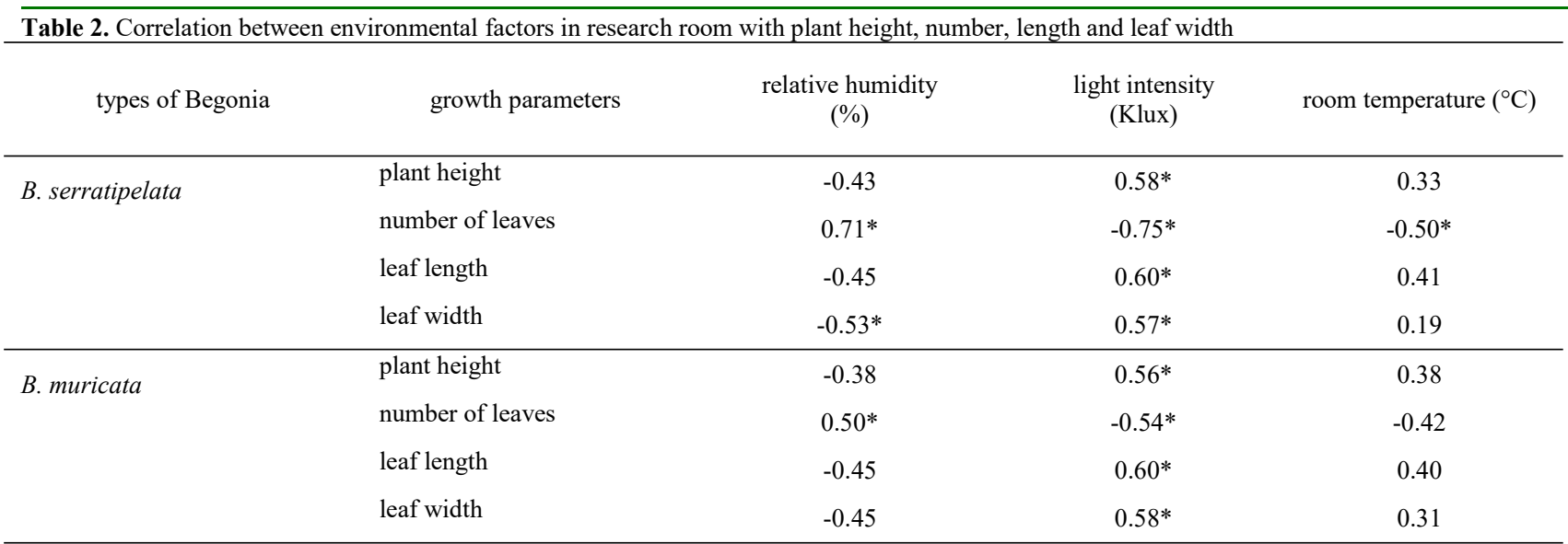

\section{Discussion}

Increase in plant height, number, width and length of begonia leaves

Begonia even though belong to indoors plant continuing to grow up to a specific time limit, as seen in Table 1. This condition is thought to be because begonia is better to adapt well to indoor environmental conditions so that it can show a good response to the observed growth parameters. Several studies have shown that begonias respond differently to different levels of shade. Sabatino et al. (2019) stated B. semperflorens-cultorum plants placed in the greenhouse resulted in increased plant height, number of lateral shoots, number of flowers per plant, flower diameter. Zhang et al. (2018) reported as the level of shading increased, the leaf area, water content, superoxide anion $\left(\mathrm{O}_{2}^{-}\right)$production rate, malondialdehyde (MDA) content and plasma membrane permeability of Begonia semperflorens also exhibited increasing.

\section{Begonia durability indoor}

The indicator of begonias durability indoor based on the growth parameters analysis of the begonia indoor. We assumed that the shorter time for growth criteria is the restriction for survive indoors. This means the plant should be carried out to the nursery for recovery. The durability of both Begonia indoor pot only until the second week. After that Begonia should be transferred to nursery or place outside semi-shade for recovery. Siregar (2008) stated the criteria for the type of Begonia that can be used as an indoor plant include easy maintenance, long-lasting in the room, beautiful leaf shape and color, resistance to low light conditions, resistant to airconditioned rooms, the leaves do not fall off quickly, and their appearance does not change much or stay good in 1-4 weeks (Siregar, 2008). Siregar and Siregar (2011) suggest tips to keep Begonia indoor fresh and not disturbed by growth must be placed outside the room periodically for one week to get fresh air and sunlight or if placed outdoors either under the shade, terrace of the house or under a tree.

\section{Effect of environmental factors on Begonia growth} after acclimatization

Environmental factor consists of temperature, relative humidity and light intensity indoor has correlation with plant growth (Table 2) According to Surendranath and Rahul (2016), the selection of indoor plants that need to be considered is lighting, potting mixes, temperature, humidity, watering, fertilizer, grooming, acclimatization, putting houseplants outside for the summer. Their research shows that most plants grow best indoor when the day temperature is 18 to $24{ }^{\circ} \mathrm{C}$ and 16 to $18{ }^{\circ} \mathrm{C}$ at night. This temperature is in line with the Bali Botanic Garden environment. For humidity, plants grow best at a relative humidity of 40 to $60 \%$. While the humidity in Bali Botanic Garden higher than ideal relative humidity.

Light intensity is an essential component in the photosynthetic process, which also affects plant growth. Low light is the most important factor influencing foliage plant performances under interior condition (Chen et al., 2005b). Chen et al. (2005b) stated that Ficus benjamina 'Common' responded to interior low light after acclimatization by enlarging leaf area, reducing leaf thickness, increasing specific leaf area, and increasing internode length to intercept more light. This result in accordance with our research which show increasing of plant height.

Several studies have stated that lighting affects the growth and leaf color of begonias (Eom and Kim, 2014; Kessler and Armitage, 1992; Nababan et al., 2018). Low light results in poor begonia plant quality, namely reduced growth and number of flowers, dry weight, shoots, lateral young leaf area, total leaf area, and the number of nodes decreasing over time, such as in Begonia $x$ semperflorens-cultorum (Kessler and Armitage, 1992). This condition is supported by Nababan et al. (2018) research which concluded that the average growth parameters such as stem diameter, plant height, leaf length, leaf width, and photosynthetic rate per unit leaf area are higher for high-light-grown plants than for those grown under low light. Sunlight intensity is directly proportional to plant growth and development The addition of artificial light such as blue Light Emitting Diodes (LED) improves red color expression in leaves Begonia rex 'Harmony's Red Robin' indoor (Eom and Kim, 2014). Their research also shows growth cha- 
racteristics of Begonia rex Harmony's Red Robin' grown indoors under different light sources after eight weeks, such as the number of leaves depend on a light source. However, the results of Jesfar et al. (2016) conducted a light level of $60 \%$ is the most suitable requirement for successful Begonia propagation through leaf cuttings.

Relative humidity has positive correlation with number of leaves and has negative correlation with leaf width (Table 2). This result is different with Mortensen (2000) who reported raising humidity from $70-81 \%$ in greenhouse increased plant diameter and plant dry weight of Begonia cv. Hanne, while a further increased decreased it again. The difference may be due to difference in another environmental factor.

\section{Acknowledgement}

This research was funded by DIPA Eka Karya Bali Botanic Garden. All author has the equal role in this research.

\section{References}

Chen J., McConnell DB., Norman DJ., and Henny RJ. 2005a. The foliage plant industry. Hort. Rev, 31(3), 47-112. doi: 10.1002/9780470650882.ch2

Chen J., McConnell DB., and Henny RJ. 2003. The importance of Asia-Originated plants to the growth of the foliage plant industry. ISHS Acta Horticulturae 620: XXVI International Horticultural Congress 47, 1-20. doi: 10.17660/ActaHortic.2003.620.47

Chen J., Wang Q., Henny RJ., and McConnell DB. 2005b. Response of tropical foliage plants to interior low light conditions. ISHS Acta Horticulturae 669, 51-56. doi: 10.17660/ActaHortic.2005.669.5

Dewitte A., Twyford AD., Thomas DC., Kidner CA., and Van J. 2011. The origin of diversity in Begonia: genome dynamism, population processes and phylogenetic patterns. The Dynamical Processes of Biodiversity - Case Studies of Evolution and Spatial Distribution, 448(1), 20-29. doi: $10.5772 / 23789$

Efendi M., and Lailaty I. 2018. Pertumbuhan stek daun Begonia multangula BL. dan Begonia isoptera dryand koleksi Kebun Raya Cibodas pada berbagai perlakuan media tanam. in PROSIDING Seminar Nasional Biologi (SEMABIO) UIN Sunan Gunung Djati, 428-434. Retrieved from https://www.researchgate.net/publication/327279182(Accesse d 27 July 2021)

Kim W. 2014. Effects of light quality on growth characteristics and red variegated expression in leaves of Begonia rex "harmony's red robin" for indoor vertical gardening system. Journal of the the Society of People, Plants, and Environment, 17(5), 365-371. DOI:10.11628/ksppe.2014.17.5.365

Girmansyah, D. 2008. Keanekaragaman jenis Begonia (Begoniaceae) liar di Jawa Barat. Berita Biologi , 9(2), 195-203. retrieved from https://ejournal.biologi.lipi.go.id/index.php/berita_biologi/article/down load $/ 2028 / 1907$

Ginori J., Huo A., and Warwick CR. 2020. A beginner's guide to Begonia: classification and diversity. EDIS 2020 (1). Retrieved from https://edis.ifas.ufl.edu/pdf/EP/EP58100 (Accessed 27 July 2021)
Temperature has negative correlation with number of leaves (Table 2). This result accordance with Myster and Moe (1995) who review average daily temperature can influence internode elongation (plant height) and leaf unfolding rate.

In conclusion, the durability of $B$. serratipetala and $B$. muricata as indoor pot was two weeks. This is the ideal limit for rotation so that the growth of begonias is still display-worthy. Sunlight intensity positively correlates with plant height, leaf and width length and negatively correlates with the number of leaves of $B$. serratipetala and B. muricata.

Hughes, M., Moonlight, P.W., Jara-Muñoz, A., Tebbitt, M.C., Wilson, H.P. \& Pullan, M. (2015-). Begonia Resource Centre. Retrieved from http://padme.rbge.org.uk/begonia/(Accessed 27 July 2021)

Jeong KY., Pasian CC., Mcmahon M., and Tay D. 2009. Growth of six Begonia species under shading. The Open Horticulture journal , 22-28. doi: 10.2174/1874840600902010022

Myster, J., \& Moe, R. (1995). Effect of diurnal temperature alternations on plant morphology in some greenhouse crops - a mini review. Scientia Horticulturae, 62(4), 205-215. doi: 10.1016/0304-4238(95)00783-P

Jesfar ABM., Rifky ALM., and Rinos MHM. 2016. Impact of propagation media and different light levels on vegetative propagation of begonia. 6th International Symposium - South Eastern University of Sri Lanka 357-365. Retrieved from https://www.researchgate.net/publication/328163815(Accesse d 27 July 2021)

Kessler J., and Armitage A. 1992. Effects of shading on growth rate, flower initiation and flower development of Begonia $x$ semperflorens-cultorum. Journal of Horticultural Science 67(6): 849-854. doi: 10.1080/00221589.1992.11516317

Mortensen, L. M. (2000). Effects of air humidity on growth, flowering, keeping quality and water relations of four short-day greenhouse species. Scientia horticulturae, 86(4), 299-310. doi: 10.1016/S0304-4238(00)00155-2

Nababan RS., Suwandi and Fathona IW. 2018. Testing the effect of light intensity on the growth of corn plants in the room. $e$ Proceeding of Engineering 5(3): 5809-5816. retrieved from https://openlibrary.telkomuniversity.ac.id/pustaka/files/145369 (Accessed 27 July 2021)

Odeh R., and Guy CL. 2017. Gardening for therapeutic people-plant interactions during long-duration space missions. Open Agriculture 2(1): 1-13. doi: 10.1515/opag-2017-0001

Sabatino L., D'anna F., Torta L., Ferrara G., and Lapichino G. 2019. Arbuscular mycorrhizal inoculation and shading enhance crop performance and quality of greenhouse Begonia semperflorens. Acta Scientiarum Polonorum, Hortorum Cultus 18(3): 17-33. doi:10.24326/asphc.2019.3.2

Siregar, HM. 2005. Begonia Kebun Raya Bali. UPT Balai Konservasi Tumbuhan Kebun Raya Eka Karya Bali-LIPI. 163p

Siregar, HM. 2008. Mengenal \& Merawat Begonia. Cetakan pertama. Agromedia Pustaka, Jakarta

Siregar HM. 2016. Four new varieties of begonia from interspecific hybridization Begonia natunaensis C.W.Lin \& C.I.Peng $\times$ Begonia puspitae Ardi'. Biodiversitas 17(2): 776-782. doi:10.13057/biodiv/d170254 
Siregar, HM., and Siregar M. 2011. Adaptasi dan seleksi 50 jenis Begonia dataran tinggi di Kebun Raya Bogor. In: Prosiding Seminar Nasional Konservasi Tumbuhan Tropika, UPT Balai Konservasi Tumbuhan Kebun Raya Cibodas 144-149.

Smith LB., Wasshausen DC., Golding J., and Karegeannes CE. 1986. Begoniaceae Part I: Illustrated Key; part II: Annotated Species List. In: Smithsonian Contributions to Botany Number 60 Begoniaceae. USA: Smithsonian Institution Press. doi: 10.5479/si.0081024X.60

Surendranath R., and Rahul N. 2016. Interior softscaping. First edition. Canada Research Publication. Retrieved from https://www.researchgate.net/publication/301593875 (Accessed 27 July 2021)

Zhang Y., Liu A., Zhang X., and Huang S. 2018. Effects of shading on some morphological and physiological characteristics of Begonia semperflorens. Pakistan Journal of Botany 50(6): 2173-2179. $\quad$ Retrieved from https://www.pakbs.org/pjbot/papers/1531142432 (Accessed 27 July 2021) 